\title{
The Trials and Tribulations of Constitutionalism and the Constitution Making Process in Zimbabwe
}

\section{Jephias Mapuva*}

\begin{abstract}
Constitutionalism in Zimbabwe has been characterised by controversy with citizens getting a raw deal. The colonial era was characterised by deprivation of basic rights and civil liberties. A plethora of constitutions were established to try and create a semblance of black representativity. The post-colonial era was informed by governance structures provided by the Lancaster House Constitutional document which was a surrender document that brought the protracted liberation struggle to an end. The vagaries of the Lancaster House Constitution lived to haunt even those who fought for the country, leading to an expression of dissatisfaction with its contents. After successive indecisive elections conducted under the Lancaster House Constitution, the political and economic crises of 2008 led to an impasse and the signing of the Global Political Agreement which gave birth to the Inclusive Government, a transitional arrangement during which a new constitutional draft would be written and put to a referendum. This paper will explore the general theory of constitutions from the Aristotelian classical perspective. Thereafter the paper will also provide an overview of the concept of constitutionalism, followed by the case of Zimbabwe from the colonial era and the various constitutional documents that existed. The recent political development and the role of civil society herein represented by the National Constitutional Assembly (NCA) will be presented and how the civic group has articulated the constitution reform debate since its inception in 1997.
\end{abstract}

Key words: Zimbabwe, constitutionalism

\footnotetext{
* African Centre for Citizenship and Democracy [ACCEDE], School of Government, University of the Western Cape-South Africa, mapuva@ cooltoad.com
} 


\section{Introduction}

A constitution seeks, among other things, to regulate the relationship between the governors and the governed. It is essentially about power demarcating as it does the limits of government and protecting the freedoms of the governed. Politics itself is about power, essentially the pursuit or retention of power - in this case, the power to govern. Political power can be achieved by persuasion, coercion or by a combination of both. The constitution and attendant secondary laws regulate how power is won or lost. A document that regulates political power or its attainment cannot therefore, be divorced from politics, no matter how desirable it might seem to have it otherwise.

Politicians with the power to govern are required to adhere to the constitution. The constitution impacts on politics to the extent that it regulates the attainment, distribution and use of political power and behaviour of political actors in a specific polity. It has been acknowledged that politics influences constitution-making. Of course, given the extent to which the constitution impacts on politics, the opposite is equally true - it's a no-brainer, one might even add. Ordinarily, law-making is a political process - involving hard bargaining and trade-offs between the political actors in a multiparty parliament. Laws are what the politicians want, in accordance with the political philosophy that influences their politics. Laws are politicians' instruments which are passed off as people laws. A constitution represents the supreme law of the land but it's a law nevertheless. The difference is that whilst ordinary laws are created in the exclusive domain of parliament, the constitution often requires direct approval by the people through a referendum. But it should be noted that once passed, the constitution is again in the exclusive domain of parliament and therefore politicians because it can be amended by at least two-thirds majority of parliamentarians.

\section{General Theory of Constitutions and Citizenship: An Aristotelian Classical Theoretical Framework}

Aristotle states that "the politician and lawgiver is wholly occupied with the city-state, and the constitution is a certain way of organizing those who inhabit the city-state". ${ }^{1}$ His general theory of constitutions is set forth in Politics III. He begins with a definition of the citizen (politês), since the city-state is by nature a collective entity, a multitude of citizens. Citizens are distinguished from other inhabitants, such as resident aliens and slaves; and even children and seniors are not unqualified citizens (nor are most ordinary workers). After further analysis he defines the citizen as a person who has the right (exousia) to participate in deliberative or judicial office. In Athens, for example, citizens had the right to attend the assembly, the council, and other bodies, or to sit on juries. The Athenian system differed from a modern representative democracy in that the citizens were more directly involved in governing. Although full citizenship tended to be restricted in the Greek city-states (with women, slaves, foreigners, and some others excluded), the citizens were more deeply enfranchised than in modern representative democracies because they were more directly involved in governing. This is reflected in Aristotle's definition of the citizen (without qualification). Further, he defines the city-state (in the unqualified sense) as a multitude of such citizens which is adequate for a selfsufficient life.

Aristotle defines the constitution as a way of organizing the offices of the city-state, particularly the sovereign office. The constitution thus defines the governing body, which takes different forms: for example, in a democracy it is the people, and in an oligarchy it is a select few (the wealthy or well born). Before attempting to distinguish and evaluate various constitutions Aristotle considers two questions. First, why does a city-state come into being? He recalls the thesis, defended in Politics I.2,that human beings are by nature political animals, who naturally want to live together.

He then adds that "the common advantage also brings them together insofar as they each attain the noble life. This is above all the end for all both in common and separately." 2 Second, what are the different forms of rule by which one individual or group can rule over another? Aristotle distinguishes several types. He first considers despotic rule, which is exemplified in the master-slave relationship. 
Aristotle thinks that this form of rule is justified in the case of natural slaves who (he asserts without evidence) lack a deliberative faculty and thus need a natural master to direct them; ${ }^{3}$ slavery is defended at length in Politics I.4-8). Although a natural slave allegedly benefits from having a master, despotic rule is still primarily for the sake of the master and only incidentally for the slave. ${ }^{4}$ (Aristotle provides no argument for this: if some persons are congenitally incapable of self-governance, why should they not be ruled primarily for their own sakes?) He next considers paternal and marital rule, which he also views as defensible: "the male is by nature more capable of leadership than the female, unless he is constituted in some way contrary to nature, and the elder and perfect [is by nature more capable of leadership] than the younger and imperfect." Aristotle is persuasive when he argues that children need adult supervision because their rationality is "imperfect" (ateles) or immature. But he also alleges (without substantiation) that, although women have a deliberative faculty, it is "without authority" (akuron), so that females require male leadership. ${ }^{6}$ (Aristotle's arguments about slaves and women appear so weak that some commentators take them to be ironic. However, what is obvious to a modern reader need not have been so to an ancient Greek, so that it is not necessary to suppose that Aristotle's discussion is ironic.) It is noteworthy, however, that paternal and marital rule are properly practiced for the sake of the ruled (for the sake of the child and of the wife respectively), just as arts like medicine or gymnastics are practiced for the sake of the patient. ${ }^{7}$ In this respect they resemble political rule, which involves equal and similar citizens taking turns in ruling for one another's advantage. ${ }^{8}$ This sets the stage for the fundamental claim of Aristotle's constitutional theory: "constitutions which aim at the common advantage are correct and just without qualification, whereas those which aim only at the advantage of the rulers are deviant and unjust, because they involve despotic rule which is inappropriate for a community of free persons". ${ }^{9}$

The distinction between correct and deviant constitutions is combined with the observation that the government may consist of one person, a few, or a multitude. Hence, there are six possible constitutional forms (Politics I.7):

\begin{tabular}{|c|c|c|}
\hline & Correct & Deviant \\
\hline One Ruler & Kingship & Tyranny \\
\hline Few Rulers & Aristocracy & Oligarchy \\
\hline Many Rulers & Polity & Democracy \\
\hline
\end{tabular}

This six-fold classification (which is adapted from Plato's Statesman) sets the stage for Aristotle's inquiry into the best constitution, although it is modified in various ways throughout the Politics. For example, he observes that the dominant class in oligarchy (literally rule of the oligoi, i.e., few) is typically the wealthy, whereas in democracy (literally rule of the dêmos, i.e., people) it is the poor, so that these economic classes should be included in the definition of these forms. ${ }^{10}$ Also, polity is later characterized as a kind of "mixed" constitution typified by rule of the "middle" group of citizens, a moderately wealthy class between the rich and poor. ${ }^{11}$

Aristotle turns to arguments for and against the different constitutions, which he views as different applications of the principle of distributive justice. ${ }^{12}$ Everyone agrees, he says, that justice involves treating equal persons equally, and treating unequal persons unequally, but they do not agree on the standard by which individuals are deemed to be equally (or unequally) meritorious or deserving. He assumes his own analysis of distributive justice set forth in Nicomachean Ethics V.3: Justice requires that benefits be distributed to individuals in proportion to their merit or desert. The oligarchs mistakenly think that those who are superior in wealth should also have superior political 
rights, whereas the democrats hold that those who are equal in free birth should also have equal political rights. assume a false conception of the ultimate end of the city-state. The city-state is neither a business association to maximize wealth (as the oligarchs suppose) nor an agency to promote liberty and equality (as the democrats maintain). Instead, Aristotle argues, "the good life is the end of the citystate," that is, a life consisting of noble actions. ${ }^{13}$ Hence, the correct conception of justice is aristocratic, assigning political rights to those who make a full contribution to the political community, that is, to those with virtue as well as property and freedom. ${ }^{14}$ This is what Aristotle understands by an "aristocratic" constitution: literally, the rule of the aristoi, i.e., best persons. Aristotle explores the implications of this argument in the remainder of Politics III, considering the rival claims of the rule of law and the rule of a supremely virtuous individual. Here absolute kingship is a limiting case of aristocracy. Again, in books VII-VIII, Aristotle describes the ideal constitution in which the citizens are fully virtuous.

\section{Study of Specific Constitutions}

The purpose of political science is to guide "the good lawgiver and the true politician". ${ }^{15}$ Like any complete science or craft, it must study a range of issues concerning its subject matter. For example, gymnastics (physical training) studies what sort of training is advantageous for what sort of body, what sort of training is best or adapted to the body that is naturally the best, what sort of training is best for most bodies, and what capacity is appropriate for someone who does not want the condition or knowledge appropriate for athletic contests. Political science studies a comparable range of constitutions: ${ }^{16}$ first, the constitution which is best without qualification, i.e., "most according to our prayers with no external impediment"; second, the constitution that is best under the circumstances "for it is probably impossible for many persons to attain the best constitution"; third, the constitution which serves the aim a given city-state population happens to have, i.e., the one that is best "based on a hypothesis": "for [the political scientist] ought to be able to study a given constitution, both how it might originally come to be, and, when it has come to be, in what manner it might be preserved for the longest time; I mean, for example, if a particular city happens neither to be governed by the best constitution, nor to be equipped even with necessary things, nor to be the [best] possible under existing circumstances, but to be a baser sort."

Hence, Aristotelian political science is not confined to the ideal system, but also investigates the second-best constitution, the one which is the best that most city-states are capable of supporting. For it is the closest approximation to full political justice which the lawgiver can attain under the circumstances. Although Aristotle's political views were influenced by his teacher Plato, he is very critical of the ideal city-state set forth in Plato's Republic on the grounds that it overvalues political unity, it embraces a system of communism that is impractical and inimical to human nature, and it neglects the happiness of the individual citizens (Politics II.1-5). In contrast, in Aristotle's own "best constitution" (described in Politics VII-VIII) each and every citizen will possess moral virtue and the equipment to carry it out in practice, and thereby attain a life of excellence and complete happiness. ${ }^{17}$ All of the citizens will hold political office and possess private property because "one should call the city-state happy not by looking at a part of it but at all the citizens." ${ }^{18}$ Moreover, there will be a common system of education for all the citizens, because they share the same end (Pol. VIII.1). But if (as is the case with most city-states) the population lacks the capacities and resources for complete happiness, the lawgiver must be content with fashioning a suitable constitution (Politics IV.11). The second-best system typically takes the form of a polity (in which citizens possess an inferior, more common grade of virtue) or mixed constitution (combining features of democracy, oligarchy, and aristocracy, so that no group of citizens is in a position to abuse its rights).

In addition, the political scientist must understand existing constitutions even when they are bad. Aristotle adds that "to reform a constitution is no less a task [of politics] than it is to establish one from the beginning," and in this way "the politician should also help existing constitutions." ${ }^{19}$ The political scientist should also be cognizant of forces of political change which can undermine an existing regime. Aristotle criticizes his predecessors for excessive utopianism and neglect of the 
practical duties of a political theorist. However, he is no Machiavellian. The best constitution still serves as a regulative ideal by which to evaluate existing systems.

These topics occupy the remainder of the Politics. Books IV-VI are concerned with the existing constitutions: that is, the three deviant constitutions, as well as polity or the mixed constitution, the best attainable under most circumstances. ${ }^{20}$ The whole of book $\mathrm{V}$ investigates political change and revolution. Books VII-VIII are devoted to the ideal constitution. As might be expected, Aristotle's attempt to carry out this program involves many difficulties, and scholars disagree about how the two series of books (IV-VI and VII-VIII) are related to each other: for example, which were written first, which were intended to be read first, and whether they are ultimately consistent with each other.

Aristotle's Politics did not have an immediate impact because it defended the Greek city-state, which was already becoming obsolete in his own lifetime. As mentioned above, the Greek city-states permanently lost their independence due to the conquest by the kings of Macedon. For similar reasons much of his discussion of particular political institutions is not directly applicable to modern nationstates (apart from his objectionable defenses of slavery, female subservience, and disenfranchisement of the working classes). Even so, Aristotle's Politics has had a deep influence on political philosophy until the present day, because it contains deep and thought-provoking discussions of perennial concerns of political philosophy: the role of human nature in politics, the relation of the individual to the state, the place of morality in politics, the theory of political justice, the rule of law, the analysis and evaluation of constitutions, the relevance of ideals to practical politics, the causes and cures of political change and revolution, and the importance of a morally educated citizenry.

\section{Constitutions and Constitutionalism}

In general terms, a constitution is a set of rules and regulations that govern the administration and composition of a country or organization. Clapham notes that "...the formal constitution of the state should in principle provide the ultimate legal framework through which rational-legal behaviour is defined". ${ }^{21}$ Kamrava concurs with this notion by pointing out that "...constitutions lay down the overall nature and the characteristics of political institutions in elaborate detail, and hold promises of institutionally guaranteed civil liberties and political democracy". ${ }^{22}$ On the contrary, constitutions "....are tailor-made to fulfil specific political purposes and to present a mere cloak of legitimacy to norms and practices otherwise considered as unpopular and illegitimate". ${ }^{23}$ Through registering and allowing civil society continued existence, the state is creating an avenue for civil society participation in national programmes that help in realizing societal objectives such as poverty alleviation, the observance of human rights, upholding of democratic principles and even environmental and HIV/AIDS awareness campaigns.

In many cases, a constitution stipulates who should do what, how and for how long (tenure of office). In the case of states, a constitution may stipulate various office bearers, their election or appointment into office, their duties and the minimum age. Very few (if any) constitutions would give the age limit for political leaders, with different reasons being put abode, ranging from "old leaders have a wealth of experience" or "experience is the best teacher" to "younger minds bring new and modern ideas". The non-provision of age limits on state presidents has created much debate in many countries in recent times.

Many constitutions skirt around or try to avoid the mention of age restrictions as a qualification to the position of a state president. The South African Constitution out-rightly avoids any mention of age or age restriction at all. The Constitution of Zimbabwe, under section....stipulates only mentions the entry age and is silent on the age limit, creating a fertile ground for possible manipulation and abuse of the office of State President. This also results in incumbent State Presidents having to cling to power and to them (and anybody else) it is within the confines of the constitution. One of the draft constitutions that have come closest to setting the entry age and age limit is the National Constitutional Assembly (NCA) that has, under Section 71, provided that any citizen of Zimbabwe 
who intends to run for the State presidency should "have a minimum age of 45 and a maximum of 65.Unfortunately, this draft constitution was rejected by the Government of Zimbabwe, preferring to use the current Lancaster House Constitution which does not give an age limit to the State President. This gives the parameters within which all those who want to stand for the position should meet. Leaving the age limit to chance have created numerous problems where even the old guard has thrown their hats into the ring, usually applying dirty tricks along the way to elbow out their opponents.

Increased cases of corruption among State Presidents (power corrupts!), debates have begun to emerge with many citizens in many parts of the world calling for the inclusion of a clause which stipulates age limits for those who would like to vie for the position of State President (or Prime Minister).

\section{The Dilemma of the Constitution-Making Process in Zimbabwe}

The constitution-making process has been one of the most revealing moments in the history of statecivil society relations in Zimbabwe. It is a process that has brought out Zimbabwe African National Union Patriotic Front (ZANU PF)'s propensity to manipulate situations that involve citizens by masquerading as possessing an inherent obligation to represent the wishes and desires of the generality of the citizens of Zimbabwe. It is also a moment when it emerged that despite the fact that ZANU PF had despised the Lancaster House Constitution as a document crafted by the imperialists in London for the Zimbabweans, at the bottom of their hearts, the people in ZANU PF have enjoyed the provisions of this 'imperialist document'. They have tried to bring back the same constitution through the back door by including and inculcating all those favourable aspects to the fore in ever constitutional document that they had the privilege to write or cause the writing of. This was first shown in the Constitutional Commission's resultant Constitutional Draft document which was rejected by the majority of citizens in 1999 at the first ever referendum in post-colonial Zimbabwe. The resultant debates about the constitution again resurfaced during inter-party discussions which brought about the signing of the Inter-Party Agreement (IPA) in September 2008, commonly referred to as the Global Political Agreement (GPA). Again it was agreed that in addition to the cession of inter-party hostilities and human rights violation by ZANU PF supporters against their opposition counterparts, as well as the enactment of a number of Commissions to deal with outstanding issues such as media freedoms and elections, under Article 6 of the GPA, the issue of the constitution making process was deliberated upon at length and a deadline of 18 months was provisionally agreed upon. However differences between parties to the Inclusive Government, as well as the Inclusive Government on one hand and civil society groups led by the NCA on the other hand also emerged. The Kariba Draft Constitution was dragged into the furore as ZANU PF insisted on having the Draft Constitution as the basis for the constitution-making process while the MDC-T formation and much of the civil society movement led by the NCA insisted that the Kariba draft constitutional document should not only form the basis for a new constitution, but should be regarded as one of the several constitutional draft constitutions from which the Constitutional Commission or whoever will eventually be obliged to lead the constitutionmaking process will draw from. The NCA and its affiliates within the civil society movement have refused to make the Kariba Draft Constitution the basis for a new constitution pointing that it has many partisan and traces of the Constitutional Commission Proposal that was rejected by the citizens of Zimbabwe in 1999 at the National Referendum. In all these deliberations, arguments and counterarguments, the citizens have been the worst affected because their views have been disregarded as politicians assume that they have an obligation to think for the people and that even in elections it is not people who have the opportunity t choose political leaders of their choice, but that the onus is on politicians to hand-pick what they regard as the most suitable political leader for the citizens. This is has subsequently been the crux of the matter as one constitutional draft after another has been presented to the people without much success as the citizens have matured to the extent that they now (of all the time in the history of Zimbabwe) understand the significance of citizen participation in governance processes. This also explains why politicians have hastened to want to lead the constitution-making process so as to grab the opportunity to land to the people a constitutional 
document that best suit the interest of politicians. Below is a critique of the Kariba Draft Constitution and how, according to the NCA, the Zimbabwe Lawyers for Human Rights and legal experts, it presented itself as a replica of the Constitutional Commission Proposal of 1999.

\section{Constitutional Developments In Zimbabwe [1961-1979]}

The history of constitutionalism in Zimbabwe is fraught with irregularities, initially during the colonial era and with controversy in the post-colonial era from 1980 to date. It is an issue which has not only courted controversy due to the partisan nature with which the ZANU PF government treated it, but has been manipulated by President Mugabe to consolidate his powers.

The issue of the constitution and the constitution-making process has been shrouded in secrecy as the documents were never presented to the ordinary citizens nor was the document ever made accessible to the general citizenry, especially so during the colonial era.

The first ever document that resembled a constitution was the charter which empowered the British South African Company (BSAC) to establish a colony in what was then called Rhodesia ${ }^{24}$ in 1895. Following the abrogation of the company's charter in 1923, Southern Rhodesia's white settlements were given the choice of being incorporated into the Union of South Africa or becoming a separate entity within the British Empire. The settlers rejected incorporation, and Southern Rhodesia was formally annexed by the United Kingdom that year. Rhodesia was an internally self-governing colony with its own legislature, civil service, armed forces, and police. Although Rhodesia was never administered directly from London, the United Kingdom always retained the right to intervene in the affairs of the colony. ${ }^{25}$

The origins of the Parliament of Zimbabwe lie in the Westminster model, introduced into Zimbabwe in the period of colonial expansion. In tracing the historical developments of parliamentary government in this country from the late 1890's to the present day, it is virtually impossible to avoid close reference to the constitutional history and developments as well. The history of the Parliament of Zimbabwe may be discussed according to constitutional developments and the first semblance of a representative institution in Southern Rhodesia was found in the Legislative Council, established in terms of the Southern Rhodesia Order in Council of 1898. British administrators and representatives of the BSAC were part of the Legislative Council and no members of indigenous groups were incorporated into the Legislative Council. African affairs were controlled by two Chief Native Commissioners, responsible to the Administrator via secretary of Native Affairs. Participation in the elections was in practice almost entirely restricted to settlers by reason of income and property qualifications which excluded a holding in the communal lands from the definition of property.

A referendum held on 27 October 1922 to determine the opinion of the White voters on whether the country should to remain under company rule; to join the union of South Africa or to be granted Responsible Government. The result of the referendum was in favour of Responsible Government with 8744 votes cast for responsible government and 5989 for union with South Africa. ${ }^{26}$ Hence, in 1923 the administration of the BSA Company under the Royal Charter ended leading to the establishment of the first Legislature in Rhodesia

The Constitution of 1923 set up a legislature with a membership of thirty, representing 15 electoral districts each with two members. The franchise was based on minimum property, income and educational qualification which again disqualified indigenous groups on a technicality. Potential black voters had to prove that they earned wages of a hundred pounds per year, at a time when few commanded even fifty pounds per year, and had to write fifty words in English. ${ }^{27}$ The Constitution of 1923 provided for a single Legislative Assembly, the cabinet consisted of only 6 ministers and was empowered to handle the departments of the civil service and daily administration. ${ }^{28}$

Between 1953 and 1863 Southern Rhodesia was part of a federation comprising Northern Rhodesia (Zambia), Southern Rhodesia (Zimbabwe) and Nyasaland (Malawi). The federal Constitution provided that the Federal Government should have control over external affairs, trade 
agreements, immigration, electricity, economic policy, all non-African education and African higher education, law, financial and fiscal policies, import and export control, communication and defence The Federal Constitution also provided for the African Affairs Board consisting of 3 European members with special responsibilities for African interests and selected African members from each territory. The main function of the board was ostensibly to protect Africans from discriminatory legislation. What would remain within the jurisdiction of the territorial governments would be African education, housing, law and order, local government and taxation, the police, mining and labour, land and water, Native affairs, African Agriculture, European agriculture in Southern and Northern Rhodesia. Rising unrest among the African population led the colonial administration to provide a token of representativity to Africans by having a Constitution that provided for the Federal Assembly [parliament] comprising 35 members including 6 Africans, 2 from each of the three territories. In 1957 the Federal Assembly was enlarged from 35 to 59 with increased African representation. There were to be 8 elected African members and 3 European members with special responsibilities for African interests taken from the original Federal Assembly. ${ }^{29}$

After a lot of lobbying with African chiefs, the colonial administration adopted the 1961 constitution which opened the franchise to all persons aged 21 years or over of all races registered on ' $\mathrm{A}$ ' roll or ' $\mathrm{B}$ ' roll ${ }^{30}$. However the restrictive qualifications for voting remained those of high income per annum and property which many Africans could not amass hence failed to vote. A Constitutional Council whose function was to scrutinize legislation in terms of the Declaration of Rights was also set up.

In 1969 after a referendum, a republican government and a new constitution were adopted. Under this Constitution the new Parliament would consists of a Senate and a House of Assembly. However, this constitutional arrangement was not in agreement with the majority rule concept, given that the out of the 65 members of the House of Assembly, 50 were Europeans and 8 were Africans. The legislature division on racial grounds was completed. The overall effect of the 1969 constitution was to entrench total political power in European hands permanently without African curbs. ${ }^{31}$

Increased unrest among the African population in tandem with the liberation struggle which had started as far back as 1966 led to a negotiated settlement started in September 1979 and ended in December 1979 which resulted in the signing of the Lancaster House Agreement of 1979 which eventually brought political independence to Zimbabwe. Parties to the Lancaster Agreement were:

- The British Government as the colonial power.

- $\quad$ The Zimbabwe-Rhodesia regime comprising UANC and RF

- $\quad$ The Patriotic Front jointly led by ZANU (PF) and (PF)-ZAPU.

On the basis of the 1979 Lancaster House Constitution, there was a return to legality and the end of war, paving way for the elections based on a universal adult franchise. The constitution provided for a bicameral parliament made up of the House of Assembly and the Senate. The House of Assembly consisted of:

- $\quad 80$ blacks being elected from eight electoral provinces by black voters

- 20 reserved white seats elected from twenty constituencies by white voters, to make up the House of Assembly.

The constitutional clause on the 20 reserved seats for whites were to be reviewed after 5 years. The Senate consisted of 40 members elected by 3 electoral colleges.

- 14 senators were elected by an electoral college of the 8 black members of the House of Assembly. 
10 Senators were elected by the white members of Parliament. The Chiefs were elected to the Senate by the Council of Chiefs in Mashonaland and Matebeleland, giving an equal number of seats for the two provinces.

- The last 6 senators were appointed by the State President acting on the recommendation of the Prime Minister.

The constitutional provisions contained in the Lancaster House Constitution presented a different picture with a thrust towards empowering Africans in total contrast to what had been the case during the colonial period.

By and large, the Zimbabwe Parliament has undergone considerable constitutional changes since independence in 1980 and, therefore can be viewed in terms of three phases:

- $\quad 1980-1989$, bicameral legislative phase.

- $\quad 1990$ - 1999, unicameral phase.

- $\quad 2006-2008$, the bicameral system introduced by constitutional amendment no. 17 of

2005.

- 2008- to date, the signing of the Global Political Agreement and the drawing up of a new constitution to replace the Lancaster House Constitution and the holding of elections under the new constitution.

\section{Separation of powers and protection of human rights in the context of the New Constitution in Zimbabwe}

Separation of powers is a model of governance for democratic states where the state is divided into three branches. The three branches are the executive (enforces laws), the legislature (makes laws), and the judiciary (interprets law), each with separate and independent powers and areas of responsibility. Governance that is based on a constitution premised on the doctrine of separation of powers safeguards the nation against abuse of power by the rulers who may want to pursue their own interests at the expense of basic rights of those they govern.

\section{The origin of the doctrine}

The term separation of powers got its scientific form from the French philosopher Montesquieu who categorized governmental functions as executive, legislative and judicial. He believed that those possessing power would grasp more powers unless checked by the other power -holders, thus the separation of powers. The epic of the doctrine came with the American independence that saw it being operationalized.

In its pure form, separation of powers assumes a separate, distinct and independent function of the three arms of government, the executive, judiciary and the legislature. In this order:

1. The same person may not belong to more than one of the three arms of government.

2. The organ of the government should not take or infringe upon the powers and work of another, for instances the judiciary should be independent of the executive and ministers should not be responsible to parliament.

3. A person holding office in one organ of government should not owe his term of office to the will or preferences of persons in any other. 
It is important to note that the doctrine of separation of powers was never meant to be rigid, with absolute separation of the arms of government. Rather it requires a system in which the risks of a concentration of powers, and the attendant dangers that go with it, can be reduced through limited interference by each of the three powers in each other's domain. However, in practice these three arms may overlap.

\section{Three Arms of Government}

\section{Executive}

The executive arm of government has sole authority and responsibility for the daily administration of the state. The separation of powers system is designed to distribute authority away from the executive branch to preserve individual liberty in response to cruel leadership throughout history. The executive is not supposed to make laws (the role of the legislature), or interpret them (the role of the judiciary). The role of the executive is to enforce the law as formulated by the legislature and interpreted by the judicial system.

\section{Legislature}

The legislature is the law-making arm of the government in Zimbabwe. It deliberates on issues and has power to pass, amend and repeal laws. In the separation of power doctrine, the legislature is equal to and independent of both the judiciary and the executive. In Zimbabwe legislative authority is vested in Parliament, which is composed of 210 Members House of Assembly and Senate, which is made up of 93 Senators.

\section{Judiciary}

The judiciary is the system of courts, which interprets and applies the law in the name of sovereign or state. The judiciary provides a mechanism for the resolution of disputes. Under the doctrine of separation of powers, the judiciary generally does not make law (which is the responsibility of the legislature) or enforce law (which is the responsibility of the executive), but rather interprets law and applies it to the facts of each case. This branch of government is often tasked with ensuring equal justice under law. It usually consists of a court of final appeal (called the "supreme court" or "constitutional court"), together with lower courts, which are the High Court and Magistrate's Courts.

\section{Constitution making}

Article VI of the Global Political Agreement (GPA) acknowledges that it is the fundamental right and duty of the Zimbabwean people to make a constitution for themselves.

The principals to the GPA, in the same article, also express their determination to create conditions for the people to write a constitution for themselves mindful of the need to ensure that the new constitution entrenches democratic values and principles and the protection of equality of all citizens, particularly the enhancement of full citizenship. There is need for all stakeholders 'participating in the constitution making process to ensure a people driven constitution that will have the ownership it deserves. When the people make the contributions to the writing of the constitution they to take into consideration the doctrine of separation of powers as a core value of constitutionalism.

\section{Separation of powers: Zimbabwean experience}


Judge President Makarau sums up the Zimbabwean experience; noting that there is gross violation of this doctrine. The executive, during the ZANU PF government, was all-powerful to the extent of stifling other arms. This has compromised the independence and the impartiality of the judiciary, and the vibrancy of the legislature. As noted by Fombard:

Whilst the separation of powers is either explicitly or implicitly provided for in a wide variety of ways, the scope for mutual checks and balances that are part of the doctrine diminish in many of these constitutions as a result of the exorbitant powers conferred on the executive to interfere with the other two branches of government. ${ }^{32}$

An example of a breach of doctrine in our current framework is the presidential powers (Temporary measures) Act [Chapter 10:20], which gives the President powers to create law. The act allows the president to make regulations when it appears to him that a situation has arisen or is likely to arise which needs to be dealt with urgently in the interests of defence, public safety, public health, public morality public order the economic interests of Zimbabwe or the general public interests and the situation cannot adequately be dealt with in terms of any other law. The role of the executive in the judiciary following the "Fast track Land reform Programme" is well documented. This presence yet another example of how the doctrine of separation of powers was distorted by the executive in Zimbabwe before the inception of the Government of National unity. Even though Chapter VIII of the Constitution of Zimbabwe provides for the body of judges, the executive is the one that appoints them to the bench. In spite of some guarantees of non interference by the executive in the operations of the judiciary has been recorded. Such, cases as noted by the Judge President Makarau need urgent attention in the constitution making process.

\section{The NCA Route to a New Constitution}

The NCA's parallel constitutional process is a worrisome development, especially given that is its proving has support of the general populace. If the large numbers that are attending the NCA constitution-making process are anything to go by, a showdown is looming between the Parliamentary Select Committee instituted by government and the NCA, especially the resultant draft constitutions of the two rivals and their adoption at the referendum. What has strengthened the position of the NCA is that it has some of the most important players in the country, namely the labour movement, the Zimbabwe Congress of Trade Unions (ZCTU)), the student movement, the Zimbabwe National Students' Union (ZINASU), as well as a host of other influential civic bodies in the country. Specialist groups previously not incorporated into public and national platforms like the youths and the disabled and those previously vindicated by government security agents like the media have also been incorporated into the realms of the NCA. This has eventually made the NCA bastion of resistance against arbitrary decision-making by state institutions, the Parliamentary Select Committee being one such organ of the state. The Movement for Democratic Change (MDC) has since distanced itself from the argument that the Kariba Draft Constitution would be the basis for a new constitution and have come up in support of the NCA on the need for a people-driven constitution derived from consultative forums with the generality of the populace.

Having been involved in the constitution reform debate for longer than any institution in Zimbabwe, the NCA views the constitution-making process as its prerogative which no other body but itself should be allowed to implement and achieve. Accordingly, it has rejected the route that has been agreed upon in the GPA and has subsequently settled for a separate route and parallel process which it views as more "people-driven" than that of government. Farai Maguwu of the Centre for Research and Development has however justified the NCA's parallel process by arguing that it is healthy for Zimbabwean democracy for both groups to hold parallel and competing conferences. ${ }^{33}$ The NCA has come up with a road-map which should be followed to come up with a people-driven constitution for the country within period stipulated in the GPA, a period of 18 months from the inception of the Inclusive transitional government. The NCA has come up a three formation that it envisages would lead to restoration of democracy in Zimbabwe. The three steps are the formation of a Transitional 
Government; the formulation of a People-Driven Constitution which would subsequently lead to Free and Fair Elections.

\section{Transitional Government}

Under this arrangement, the NCA suggests the creation of a Transitional Government which should be set up immediately to address the current humanitarian crisis. It should bring food to the people, open closed schools, make hospitals work, and ensure that basic commodities are available and affordable for all

\section{People-Driven Constitution}

Under the constitution-making process, the NCA gives more details, especially given that it is the area which it is most interested in. The NCA believes that it is the right of the Zimbabwean people to write a constitution for themselves, and as such is opposed to a situation where the process is left to political parties, as provided for under Article 6 of the Global Political Agreement signed on 15 September 2008. Accordingly, the NCA recommends a people-driven constitution-making process characterised by the following:

(i) An All Stakeholders Conference which brings together over 3000 citizens from all sectors of Zimbabwean society, including government, political parties, trade unions, business, churches, women's groups, youth, the disabled, human rights organisations, academia, farmers, veterans of the liberation struggle, people living with HIV/AIDS, traditional leaders, media, the diaspora and broader civil society

(ii) An All Stakeholders Commission, elected at the All Stakeholders Conference, will spearhead the constitution-making process.

(iii) Comprehensive Public Consultation that solicits the input of ordinary Zimbabweans on constitutional issues.

(iv) A Draft Constitution complied by the All Stakeholders Commission and presented to the public at the Second All Stakeholder Conference. Input should be collected and incorporated into a Final Draft Constitution.

(v) A National Referendum in which all Zimbabweans can vote for or against the Draft Constitution. If the Draft passes the Referendum, it becomes the new Constitution of Zimbabwe after formal enactment by Parliament. In constitution-making, the role of Parliament is to rubber-stamp the wishes of the people as expressed in the referendum.

The NCA recommends that during the lifespan of the Transitional Government, Zimbabweans must be allowed to write their own Constitution in an open and transparent process as outlined in the Zimbabwe People's Charter (2008). The resulting Constitution should be submitted to a national referendum.

\section{Free and Fair Elections}

Free and fair elections should be held under the new Constitution, leading to the installation of a new, democratic government. These elections should be internationally supervised and monitored. 


\section{Prospects for a new Constitution in Zimbabwe and the Current Position}

Given the difference in approach between the government and civil society there is bound to be a protracted battle for hegemony in the constitution-making process, especially given that the NCA has embarked on a parallel constitution-making process. This is likely to widen the already existing rift between political parties in the Inclusive Government and the wider section of civil society movement led by the NCA. If the rejection of the Constitutional Commission Proposal at the national referendum is anything to go by, then the Kariba Draft Constitution which is supported by sections of the Inclusive Government and opposed by civil society, does not stand a chance at any referendum. Therefore the prospects for a "people-driven" constitution rests with both the government and civil society coming to a compromise, especially on the modus operandi of the process of coming up with a constitutional draft agreeable to both political parties and civil society. Subsequently both the state and civil society should be prepared to give concessions in the constitution-making process.

Currently the constitutional making process is underway with outreach teams out to solicit the views of Zimbabweans about what they want in the new constitutional document. However, the Kariba Draft has again caused chaos as ZANU PF has gone all out to coerce citizens to express the view that they want the Kariba Draft which perpetuates the tenure of the State President. As a result, media reports and reliable sources have confirmed the existence of state security agents who have been sent into rural areas to force people either refuse to participate in the constitution-making process or show preference of the Kariba Draft Constitution. In some cases, politically-motivated violence has been directed at these who have participated or mobilised people to participate in the opiniongathering exercise conducted by the Committee of Parliament on the new Constitution (COPAC) teams, with some activists having been arrested for mobilising people to participate in the constitutionmaking process. Traditional leaders, who have often formed an extension of ZANU PF-enforcement agents in recent years, have also been manipulated to ensure that people within their areas comply with the directive of non-compliance with the constitutional outreach teams or alternatively to show preference for the Kariba Draft.

\section{Role of Parliament in Constitutional Reform Process in Zimbabwe: Post Drafting}

The constitutional reform process in Zimbabwe is limping heavily, with more obstacles ostensibly lying ahead. The process as envisaged by the GPA is premised to culminate in a 2nd All Stakeholders' Conference, which will produce a draft constitution. The draft constitution and accompanying report are then tabled in parliament before the draft is subjected to a referendum, according to article 6 (C) V and V11.The report and accompanying draft constitution will be debated for a month in parliament before being subjected to a popular vote. What role parliament and the executive plays, with regard to their legislative authority, towards the draft constitution emerging from the All Stake holders' Conference, remain an elusive and controversial issue. This is further complicated by effects of the Referendum Act 1999 [2.10], which provide the Executive President with unlimited powers over the process.

Sadly Zimbabweans have been left not any wiser because of the lack of clarity on this matter in the GPA, or further directions from the Minister of Constitutional Affairs, except the lingering silhouette legacy of the Mushayakarara case. Nothing aptly demonstrate this quagmire and danger more than the debacle of the Chidyausiku Commission in 2000. The Constitutional Reform Commission, appointed in terms of the Commission of Inquiries Act, produced a draft constitution which was gazetted on 30 November 1999.This Gazetted draft contained some clauses totally divergent from the original draft. Exacerbating the situation, President Mugabe on 19 January 2000, published a further draft which contained 44 so called 'Corrections and Clarifications'. Principally included was a new clause on 57, a clause allowing the state to compulsorily acquire land without compensation. 14 of the 44 Corrections and Clarifications actually substantially altered original clauses of the draft constitution, before it was subjected to a referendum. Shortly the after rejection of the draft 
in a referendum on February 12-13, 2000, the amended Section 57 [on compulsory acquisition of land] of the draft found expression in the constitution through ZANU PF fourth parliaments' last act in tenure through amendment No 16.The amendment of the draft was the subject of litigation in the Mushayakarara case. The constitution of Zimbabwe provides in Section 32 that the legislative authority of Zimbabwe 'shall vest in the legislature, which shall consist of the President and Parliament. Furthermore, Parliament is given sole responsibility 'to amend, add or repeal any provision of the constitution by Section 52.The procedure for making law [through enactment, repealing and adding] is that subject to a quorum of a simple majority of both houses, legislators can make or amend any law, including constitutional law. The threshold barrier of simple majority is raised to absolute majority if the bill under discussion is a constitutional amendment bill by Section 52 [c].The authority to amend the constitution, is like other laws, vested in parliament.

The heading under Section 52 of the Zimbabwe constitution is 'Alteration of the Constitution', which is expanded by 52[1] to mean 'amend, add to or repeal'. Under Section 113 on Interpretation, 'amend' is defined as to include 'vary, alter, modify or adapt'. Analogous terminology is used in Kenya's constitution. [Which also became a focal point of litigation in the Kenyan High Court]. Section 47 of the Kenyan constitution states 'Parliament may alter the constitution'. Furthermore, alteration is defined as to mean 'amendment, modification or enactment of a provision or the suspension or repeal of such a provision or the replacement of a provision of the constitution.' A strict interpretation of the aforesaid point to the fact that Section 52, like Kenya's section 47, does not empower parliament to make wholesome changes to a constitution, nor revoke it, but rather empowers parliament to make piecemeal changes to the constitution. The roots of the verbs amend, alter, adapt and modify signify a moderate change to an existing structure, short of overhauling it. This point is very relevant when the current constitutional reform process reaches the stage when the draft will be tabled before parliament. The crucial question is whether parliament will treat the draft as any other constitutional bill, with powers to amend, add or modify using legislative powers under Section 52? Principally if the bill is considered as any other amendment bill, it renders the whole logic of public participation and constituent power irrelevant, disempowering the citizenry who ought to author the constitution, whilst effectively ensuring that sectional interests of the major political parties will dominate the debate in parliament.

There is a school of thought recognising that writing a new constitution is not the same as making constitutional amendments, as reform is deemed as seeking to substitute the whole constitutional make up with a new constitutional order. Alteration on the other hand, is understood to be a process of changing certain clauses in a constitutional document without necessarily substituting the whole document. The current Zimbabwean constitution provides in express terms the procedure for amending the constitution. It provides that a constitutional amendment has to be affirmed by two thirds of both Houses of Parliament. Precedent has shown that this express provision applies solely to amendments as opposed to wholesale reform of the constitutional order. As of now, the original Lancaster House constitution has been amended 19 times in 30 years. Put in other words, does the constitution of Zimbabwe allow parliament to revoke it [constitution]? Probably not. Parliament in its ordinary legislative process cannot formulate a new constitutional reform bill and pass it as it does not have the power to do thus. In other words, the constitution did not provide on the process of bringing a new constitution into life. [Before the GPA, which found expression through amendment No 19].

Therefore if this school of thought is adopted, it means that parliament as it stands right now does not have any powers to effect or give effect to a new constitution. Some constitutions have entrenched the process in the constitution, recognising and providing for its own total replacement. Not only does the entrenchment provide the power to replace, it also crucially provides the process and stages to be followed when a new constitution is to be enacted. The logic behind this reasoning is that parliament itself is a product of the constitution; therefore it has no power to bring the same into life. The power to replace the constitution vests directly in the people themselves and cannot be exercised by parliament on their behalf. Theorists refer this as constituent power of the people. They note the constituent power can only be exercised through constituent assemblies elected directly by the people with express mandate to replace the constitution with another. It has also been recognised that a constituent power can also be expressed through a referendum, a process which the Zimbabwean 
constitutional reform process has adopted. Therefore what's the essence then of tabling the draft in parliament when the constituent power vests in the referendum. If this holds water, any provisions in the draft that parliament want resolving or further consultation must be returned to the All Stakeholder Conference for further deliberations and adopted as such by such a body tasked to produce the draft constitution.

Parallel to this thought are those who want to recognise that parliament in exercise of its unquestionable absolute legislative power as provided under section 32 and 52 was constitutionally authorised to alter any part of the constitution and therefore, all sections of the constitution. They recognise that parliament has unlimited authority to alter the constitution, section by section which in totality would amount to replacing the constitution with a new order. Already parliament has effected far reaching constitutional changes since 1980 which include changing the form of government from a Prime Ministerial Westminster type to executive presidency, abolishing bicameral legislative body in the late 1980, and then back again to bicameral in 2007. The 19 amendments have substantially altered the original document, though short of overhauling it.

However, the first interpretation sounds more logical and in tandem with modern democratic principles. It remains a fact that parliament on its own cannot write a new constitution for us, that would actually amount to a revolution. Two cases in Kenya confirmed this interpretation in the High Court. First was the Ringera Judgement and secondly, the Ngamu Judgement. On a point of law, different sittings in the High Court ruled that the current Kenyan constitution did not allow parliament to revoke it or establish a new constitutional order, vide section 47 , which is very similar to Zimbabwe's section 52.

Therefore it is imperative that that the Justice Minister explains to the nation what role parliament will play when the draft is presented before them and if they have powers to amend, alter or modify the draft before it is submitted to the referendum. As happened in 2000, what powers also does the executive have on the draft before it is submitted to the referendum. The danger is that, in worst case scenario, we are going to end up with the Kariba draft. How? In the Mushayakarara and Obey Mudzingwa Vs Chidyausiku petition, Justice Bartlett was asked to adjudicate on the powers of the President as provided by the Referendum Act. He ruled then that the Referendum Act 1999 did not require the President to put before a referendum a constitution approved by the then Constitutional Commission. In other words, he [President] was entitled to put any draft to the electorate and it was up to the electorate to affirm or reject that draft. Alarmingly, for the current process, Justice Bartlet further ruled that the President through the Referendum Act is entitled to make any corrections, clarifications, alterations or amendments to the draft constitution if he so wishes and does not even need the approval of parliament or any other institution for that matter! This still stands as good law and the current process envisaged by the GPA, which requires a referendum will be held through the Referendum Act, a law principally administered by the executive. Yes, we could end up with the Kariba draft or whatever ZANU PF so wishes. The MDC should have pushed for a robust process under article 6 of the GPA removing the president's power to amend the draft. To curtail such excesses, the following could provide a smoother passage for the draft, if ever it will be produced!

1. The Referendum Act must be repealed before the next referendum, removing unlimited powers for the presidency to interfere with the process.

2. Parliament must not be allowed to modify, amend, and alter any provisions of the draft constitution before it is subjected to a referendum. Such task must be done by the drafting organ of the all stakeholders' conference after shifting through materials from thematic committees. The three principals could agree on this principle.

3. Next constitution must also provide for its own overhauling expressly and the stages necessary to affect a constitutional changeover.

\section{Conclusion}


The spirit of constitutionalism is in the separation of powers between the judiciary, executive and legislature. This very ancient practice forms the basis of all democratic societies. Zimbabwe subverted this noble doctrine when it allowed the executive to dominate the other arms of government in the past. Now it this incumbent that we correct the situation and the drafting of a new constitution provides us with an opportunity to do so. As people write their own constitution they must be wary of this (doctrine of separation of power) and ensure that measure are put in place to ensure that the doctrine is not violated. A worrisome scenario seems to be unfolding in Zimbabwe, given that the parties to the Global Political Agreement undertook to have a new constitution in place within 18 months before watershed elections are held which will determine who will preside over the affairs of the country for the next five years. What this paper has concluded from the events in Zimbabwe over the constitution-making process is that while civil society has a genuine concern over the issue that the constitution-making process cannot be left to politicians, it is also necessary for civil society to realise that such a vital process should be a concerted and collaborative effort by both civil society and the state. One party cannot take it all alone as there are chances that subjectivity will carry the day. There are chances that with civil society being dependent on donor funding, the donors are likely to influence the final constitutional document, thereby compromising its relevance ad 'peopledrivenness'. Politicians alone can also come up with a document like the Kariba Draft Constitution which is in their favour and not that of the citizens. In the current scenario, citizens are being used as a scapegoat by both civil society and the state and sine the controversial Kariba Draft Constitution have not been presented to the electorate to decide. After all, the fact that it was crafted by politicians alone without the participation of citizens makes it null and void insofar as being a "people-driven" draft constitution.

\section{NOTES}

\footnotetext{
${ }^{1}$ M. F. Burnyeat, "Utopia and Fantasy: The Practicability of Plato's Ideally Just City", Psychoanalysis, Mind and Art, ed., J. Hopkins and A. Savile, Oxford: Blackwell, 1992, p. 178 [reprinted in Plato 2: Ethics, Politics, Religion, and the Soul, ed., Gail Fine (Oxford: Oxford University Press, 1999)]

${ }^{2}$ M. F. Burnyeat, "Culture and Society in Plato's Republic", The Tanner Lectures on Human Values, vol. 20, (ed)., Grethe B. Peterson (Salt Lake City: University of Utah Press, 1999), 225.

${ }^{3}$ M. F. Burnyeat, "Culture and Society in Plato's Republic", The Tanner Lectures on Human Values, vol. 20, (ed)., Grethe B. Peterson (Salt Lake City: University of Utah Press, 1999), 225.

${ }^{4}$ M. F. Burnyeat, "Culture and Society in Plato's Republic", The Tanner Lectures on Human Values, vol. 20, (ed)., Grethe B. Peterson (Salt Lake City: University of Utah Press, 1999), 227.

${ }^{5}$ J. Annas, "Plato's Republic and Feminism", Philosophy, 51 (1976), p. 315.

${ }^{6}$ M. F. Burnyeat, "Culture and Society in Plato's Republic", The Tanner Lectures on Human Values, vol. 20, (ed)., Grethe B. Peterson (Salt Lake City: University of Utah Press, 1999), 225.

${ }^{7}$ M. F. Burnyeat, "Culture and Society in Plato's Republic", The Tanner Lectures on Human Values, vol. 20, (ed)., Grethe B. Peterson (Salt Lake City: University of Utah Press, 1999), 225.

${ }^{8}$ J. Annas, "Plato's Republic and Feminism", Philosophy, 51 (1976), p. 317.

9 J. Annas, "Plato's Republic and Feminism", Philosophy, 51 (1976), p. 309.

${ }^{10}$ A. Saxonhouse, "The Philosopher and the Female in the Political Thought of Plato", Political Theory, 4 (1976), p. 199 [reprinted in Plato's Republic: Critical Essays, ed., Richard Kraut (Lanham, MD: Rowman \& Littlefield, 1997]

${ }^{11}$ A. Saxonhouse, "The Philosopher and the Female in the Political Thought of Plato", Political Theory, 4 (1976), p. 199

${ }^{12}$ R. Mayhew, Aristotle's Criticism of Plato's Republic, Lanham, MD: Rowman \& Littlefield, 1997, p. 22.

${ }^{13}$ R. Mayhew, Aristotle's Criticism of Plato's Republic, Lanham, MD: Rowman \& Littlefield, 1997, p. 22.

${ }^{14}$ R. Mayhew, Aristotle's Criticism of Plato's Republic, Lanham, MD: Rowman \& Littlefield, 1997, p. 18.

${ }^{15}$ A. Bloom, "Interpretive Essay", The Republic of Plato, trans. with notes and an interpretive essay (New York: Basic Books, 1968), 347.

${ }^{16}$ A. Bloom, "Interpretive Essay", The Republic of Plato, trans. with notes and an interpretive essay (New York: Basic Books, 1968), 350.

${ }^{17}$ D. Clay, "Reading the Republic", Platonic Writings, Platonic Readings, (ed)., Charles L. Griswold, Jr., New York: Routledge, Chapman, and Hall, 1988, p. 20.
} 
${ }^{18}$ D. Clay, "Reading the Republic", Platonic Writings, Platonic Readings, (ed)., Charles L. Griswold, Jr., New York: Routledge, Chapman, and Hall, 1988, p. 21.

${ }^{19}$ S. Rosen, Plato's Republic: A Study, New Haven: Yale University Press, 2005, p. 7.

${ }^{20}$ S. Rosen, Plato's Republic: A Study, New Haven: Yale University Press, 2005, p. 38.

${ }^{21}$ Clapham, 1992, p. 44. ???

${ }^{22}$ Kamrava, "Pseudo-Democratic Politics and Populist Possibilities: The Rise and Demise of Turkey's Refah Party”, British Journal of Middle Eastern Studies, vol. 25, no. 2, November, 1998, p. 294.

${ }^{23}$ Kamrava, "Pseudo-Democratic Politics and Populist Possibilities: The Rise and Demise of Turkey's Refah Party”, British Journal of Middle Eastern Studies, vol. 25, no. 2, November, 1998, p. 294.

${ }^{24}$ Rhodesia was named after Cecil Rhodes.

${ }^{25}$ Alistair Boddy-Evans "A Brief History of Zimbabwe - Part 1"- African History Guide

${ }^{26}$ M. I. Hirsch, A Decade of Crisis: Ten Years of Rhodesian Front Rule, Salisbury, P. Dearlove, 1973, p. 25.

27 Sylvester, 1991, p. 31.

${ }^{28}$ Sylvester, 1991, p. 31.

${ }^{29}$ Sylvester, 1991, p. 33.

${ }^{30}$ Roll "A" was for whites and Roll "B" for Africans

${ }^{31}$ M. I. Hirsch, A Decade of Crisis: Ten Years of Rhodesian Front Rule, Salisbury, P. Dearlove, 1973, p. 25.

${ }^{32}$ C. M. Fombard, "Protecting Constitutional Values in Africa: A Compararison of Botswana and Cameroun", The Comparative and International law Journal of Southern Africa, 2003, No. 36 (1), p. 83-105.

${ }^{33}$ Irwin Chifera, Jonga Kandemiiri \& Patience Rusere, "Civic Group Urges Halt to Zimbabwean Constitutional Revision Process", Available on http://www.voanews.com, Accessed on 28 July 2009 